We cordially recommend it to our readers, and we look forward with interest to the appearance of the author's companion book on laryngology.

D. $G$.

\title{
Leŗons sur les Suppurations de l'Oreille Moyenne et des Cavités Accessoires des Fosses et leurs Complications (Lessons on Suppurations of the Middle Ear and the Accessory Cavities of the Nasal Fosse, and their Complications). By Dr. Luc. (Second revised and augmented edition, with 39 figures in the text.) Paris: J. B. Baillière et Fils, 1910.
}

Dr. Luc's work is pre-eminently characterised by the utmost conscientiousness, and in his modest but masterly preface to the second edition of the book now before us he shows the spirit in which the revision and extension of the work has been carried out. He is one of those who looks his failures in the face and teaches to others the lessons which these have taught him, thus making his ultimate suceess thoroughly deserved and his instructions peculiarly valuable. Those who appreciate this mode of thought and action will be highly gratified with the book now before us.

It originally consisted of 500 pages, but the revision has been so careful that there are only eighty-four pages more in addition. In the new matter we have of course the question of suppurative labyrinthitis, the discussion of the diagnosis of which Dr. Luc has relegated to his friend and colleague Dr. Hautant, whose monograph gave the greatest impulse to the study of what we must call the Bárány tests in France. Sub-periosteal temporal abscess independent of intra-osseous suppuration is clinically met with, as the reviewer can testify from his own experience, but from the singularly few reports of cases of the kind he ventures to think that their nature is sometimes overlooked, and he almost suspects that operations on the bone have been carried out unnecessarily on the supposition that some intra-osseous focus of suppuration was present. On this account Dr. Luc's chapter on this subject should be read with the greatest attention. He seems to have arrived independently at a course of action recommended many years ago by Gruber, ${ }^{1}$ namely, that when the inflammatory swelling behind the ear is mainly situated above the level of the meatus, the chief incision of the counter-opening at least should be in the upper wall of the meatus.

A section has been added upon the treatment of tuberculosis of the larynx, and in this is inculcated a hopefulness which was formerly seldom entertained. The value of treatment by means of galvano-cauterisation is strongly emphasised, it being specially insisted on that it is never followed by dyspnoea even when practised in the glottis.

The other chapters of the book show ample signs of revision in the light of the author's conscientious study of the actual facts observed by him during his long and thoughtful experience.

D. $G$.

The Optic Nerve and the Accessory Sinuses of the Nose: a Contribution to the Study of Canalicular Neuritis and Atrophy of the Optic Nerve of Nasal Origin. By Professor A. Ononi (Budapest). Authorised translation by J. Lǘск ноғF, M.D.Edin., Ch.B. (Cape Town), with fifty illustrations. London: Baillière, Tindall \& Cox, 1910.

Prof. Onodi has applied his keen power of anatomical investigation to a study of the optic nerve in relation to the accessory sinuses of 1 "Diseases of the Ear," translated by Law, 2nd edit., p. 347. 